\title{
ECOLOGICAL SURVEY OF RIVER HABITAT DIVERSITY: TRANS-BOUNDARY COOPERATION IN THE ORE MOUNTAINS (KRUŠNÉ HORY, ERZGEBIRGE)
}

\begin{abstract}
MATOUŠKOVÁ, M., WEIß, A., MATSCHULLAT, J. (2010): Ecological survey of river habitat diversity: trans-boundary cooperation in the Ore Mountains (Krušné hory, Erzgebirge). Geografie, 115, No. 3, pp. 284-307. - Results of a trans-boundary ecological survey of the cross-border Rolava and Weisseritz river catchments in the Erzgebirge / Krušné hory are presented. An optimized method to assess the ecohydrological status of streams in keeping with the European Water Framework Directive has been developed. Guiding parameters for the hydromorphological survey were selected, used for (1) the German "Gewaesserstrukturguetekartierung" by the Field Survey method of the Laenderarbeitsgemeinschaft Wasser, (2) the Czech EcoRivHab method and (3) the Czech HEM method that additionally comply with the requirements of the European Standard EN 14614. Hydrochemical monitoring supported the interpretation of the hydrobiological data. The assessment followed the stream type specific background and orientation values. Hydrobiological monitoring focussed on benthic macroinvertebrates, stream type, and stressor specific assessment. Five ecohydrological quality classes were established from 1 (high) to 5 (bad), characterizing the state of the water course in the WFD context.

KEY WORDS: ecological survey - hydromorphology - diversity - LAWA - EcoRivHab - EN $14614-$ WFD.
\end{abstract}

We gratefully thank the Czech Ministry of Education for its support of the interdisciplinary research project MSM 0021620831 on the Rolava catchment, the German Federal Ministry of Education and Research for their generous support of the EMTAL project (BMBF, FKZ 02 WT 0078) with the Weisseritz catchment. We thankfully acknowledge support by the Saxon State Authorities and Administrations, LFUG, LTV, and the Water basin Authority Povodí Ohře, s. p., CHMI Prague, for data and information.

\section{Transboundary cooperation in ecohydrological stream survey under the EU WFD}

The European Water Framework Directive (WFD) became the fundamental basis for any water policy-related action of the European Community in December 2000. Extensive rules and regulations were developed to protect and manage waters in Europe. Until late 2015, all European surface and groundwater bodies shall attain or maintain the existing "good status", defined by a good ecological and chemical status (EC 2000).

The WFD requires a trans-border and river basin-based examination. This new approach is particularly important in the Elbe River district for the SaxonCzech-border area. 33.7\% of the entire Elbe catchment area are part of Czechia, and $12 \%$ belong to Saxony (LfULG 2008). Experts determined responsibilities 
for the 31 trans-boundary water bodies and the joint assessment programme on behalf of the co-ordination group for the WFD-implementation of the Saxon Standing Committee and the German-Czech-Commission on trans-border rivers. The Wilde Weisseritz is one of these trans-border water bodies. Almost $7.6 \%\left(12.3 \mathrm{~km}^{2}\right)$ of the upper catchment area are situated on Czech territory, and the river forms the border along $1 \mathrm{~km}$. Both, Weisseritz and Rolava basins, belong to the Elbe River basin district. The Weisseritz flows straight into the Elbe at Dresden, while the Rolava meets the Eger (Ohře), joining the Elbe further downstream.

Both river basins were already part of a hydromorphological assessment within the WFD (Weiß et al. 2008). The work summarized WFD criteria and descriptions for hydromorphological quality components and monitoring demands. Later, the quality of different European, German and Czech approaches was tested. Three different methods of stream habitat survey were applied in a practical assessment: two German field and overview survey standards by LAWA (Weisseritz basin), and the new Czech field survey method EcoRivHab (Rolava basin). Results were used to test the comparability of the methods and the suitability to fulfil the WFD and CEN standard requirements.

\section{Ecohydrological monitoring of water bodies in Saxony/Germany and Czechia}

Ecohydrological methods are complex assessment methods integrating hydrological, biological and ecological approaches (Bain et al. 2000). The ecological status of river ecosystems is usually evaluated following hydromorphological features of riverbed, flow regime and groundwater connectivity; physico-chemical parameters of water quality, biological water quality assessment, character of the riparian belt and of the floodplain, and human impacts. These parameters define the ecological integrity of any aquatic ecosystem. Their assessment is needed to enable integrated management and to protect water bodies.

The WFD (Annex V, 1.1.1; EC 2000) describes the quality elements for the classification of the ecological status of rivers. These include biological (composition and abundance of aquatic flora and benthic invertebrate fauna, composition, abundance and age structure of fish fauna), hydromorphological (hydrological regime, river continuity, morphological conditions), and chemical and physico-chemical elements, the latter both supporting the biology (general parameters and specific pollutants).

\subsection{Germ a ny}

A fundamental revision and adaptation of existing methods of biological and chemical water quality assessment was needed to implement the WFD in Germany (e.g., DIN and LAWA standards, DEV 1992, 1993, 2004; LAWA 1998) or new methods developed to fulfil the WFD requirements (EC 2000). Various projects dealt with this task from 2000 to 2006 (e.g., AQEM Consortium 2005; Braukmann, Biss 2004; Diekmann et al. 2005; Meier et al. 2006; Mischke, 
Behrendt 2007; Rolauffs et al. 2004; Schaumburg et al. 2006), and extensive practical applications were done. Methods are available since 2006 for fieldand lab-sampling, calculation, stream-type and stressor specific assessment of the biological quality components (benthic macroinvertebrates: PERLODES/ ASTERICS, fish fauna: FIBS, macrophytes/phytobenthos/diatoms: PHYLIB, and phytoplankton: PhytoFluss). These were applied in the monitoring programmes 2006-2008 for the first river basin management plans. Inter-calibrations were carried out to safeguard the international compatibility of the biological methods. No standard method was developed in Germany to describe the hydromorphological quality components, because hydromorphology received minor significance in the ecological status assessment (LfULG 2008). The two methods for stream habitat survey in Germany, (1) a field survey for small to medium-sized waters (Vor-Ort-Verfahren, LAWA 2000) and (2) an overview survey for larger rivers (Uebersichtsverfahren, LAWA 2002) are applied in very different ways. Some states use the overview method, other the field method, and some their own (e.g., Nordrhine-Westfalia, LUA NRW 2001).

Both LAWA-methods are mutually irreplaceable (Weiß et al. 2008). The overview method provides good results when large areas need to be evaluated, but seem to overestimate the true quality of the aquatic ecosystem. The field method provides more accurate information on morphological characteristics of river, riparian belts and floodplain. The relative additional effort of field mapping is overcompensated by the quality of the outputs that are fully compatible with WFD aims. The field method is thus the favourable method to assess morphological conditions and river continuity (Weiß 2007; Weiß et al. 2008). Discharge quantity and dynamics are usually registered at gauging stations. Measurement results are published, e.g., in hydrological year-books and in monthly reports, including short-time and long-time comparative evaluations. All other hydromorphological elements, such as river depth and width variation, structure and substrate of the river bed, structure of the riparian zone, river continuity and connection to groundwater bodies can be investigated and assessed by the field survey method (LAWA 2000).

Hydromorphological conditions usually represent a good ecological status from an index < 3.6 (LfULG 2008). The hydromorphological quality component is used within the WFD to determine the reasons for a biological status of lesser quality. It supplies the basis for actions that may improve the ecological status. Chemical parameters are used to assess the chemical status and the ecological status. The chemical status is described by the so called CHEM list parameters, e.g., organohalogen compounds, trace metals, biocides, cyanides (especially hazardous persistent, bio-accumulative and toxic pollutants). Chemical quality components, e.g., specific synthetic and non synthetic pollutants (so called ECO list parameters), and basic physico-chemical parameters are used to assess the ecological status. Parameters of CHEM and ECO lists are not considered in this paper. The assessment of the basic physico-chemical parameters is carried out based on preliminary stream-type specific orientation values (LAWA 2007; Tab. 1). If biological components were evaluated not to be good, then the orientation values can help to identify pressures. Results of the Federal States are currently being verified, based on available monitoring data (LfULG 2008). 
Tab. 1 - Background and orientation values for the common stream types 5 and 9 in siliceous highlands (preliminary specification by LAWA 2007; *: depends on fish region, increase in temperature caused by discharge: type 5 max. 1,5 Kelvin, type 9 max. 3 Kelvin; BOD5: uninhibited; ** background values are not useful for $\mathrm{pH}$-value)

\begin{tabular}{|c|c|c|c|c|c|c|c|c|}
\hline $\begin{array}{l}\text { Tempera- } \\
\text { ture }\end{array}$ & Oxygen & Chloride & $\mathrm{P}_{\text {tot }}$ & o- $\mathrm{PO}_{4}-\mathrm{P}$ & $\mathrm{NH}_{4}-\mathrm{N}$ & TOC & $\mathrm{BOD}_{5}$ & $\mathrm{pH}$-value \\
\hline${ }^{\circ} \mathrm{C}$ & $\mathrm{mg} / \mathrm{l}$ & $\mathrm{mg} / \mathrm{l}$ & $\mathrm{mg} / \mathrm{l}$ & $\mathrm{mg} / \mathrm{l}$ & $\mathrm{mg} / \mathrm{l}$ & $\mathrm{mg} / \mathrm{l}$ & $\mathrm{mg} / \mathrm{l}$ & \\
\hline $\begin{array}{c}\text { seasonal } \\
\text { variability }\end{array}$ & $\begin{array}{c}\text { seasonal } \\
\text { variability }\end{array}$ & mean & mean & mean & mean & mean & mean & $\min -\max$ \\
\hline \multicolumn{9}{|c|}{ Background values } \\
\hline$<18-<25 *$ & $>9$ & 50 & 0.05 & 0.02 & 0.04 & 5 & 2 & ** \\
\hline \multicolumn{9}{|c|}{ Orientation values } \\
\hline$<20-<28 *$ & $>7$ & $<200$ & $<0.1$ & $<0.07$ & $<0.3$ & $<7$ & $<4$ & $6.5-8.5$ \\
\hline
\end{tabular}

The ecological status classification depends on the most sensitive quality component. The worst component determines the overall assessment. Monitoring results and classification of the ecological status are presented in the five classes: high, good, moderate, poor and bad.

\section{2. $\mathrm{Cz}$ e c hi a}

Essential surface water monitoring in Czechia is formed by three partial programmes: (i) Situation monitoring (chemical and ecological status of water); (ii) quantitative monitoring (runoff regime) and (iii) operational monitoring (for individual river basins).The Czech Ministry of the Environment approved individual binding methodologies to monitor and evaluate the components of surface water ecological status: Kokeš, Němejcová (2006); Heteša, Marvan (2006); Grulich, Vydrová (2006); Liška (2007) and Langhammer (2007, 2008). To determine chemical composition in the monitoring profiles, water samples are taken twelve times a year for basic chemical analysis (oxygen regime indicators; chemical indicators; biological and microbiological indicators; specific contaminants) and their standard evaluation in Czechia is done following ČSN 757221 (1998). The investigation on macroinvertebrates in flowing shallow rivers follows the methodology of Kokeš and Němejcová (2006), using the PERLA method, which compares a reference locality with the locality to be evaluated. The macrozoobenthos community is then predicted and compared to the same community found at the given locality. A comparative data set from non-polluted localities is therefore mandatory. The PERLA system was created in 1996-2004 as part of projects of the Water Management Research Institute, the Agricultural Water Management Authority, and Masaryk University, all Brno. Phytoplankton sampling and processing follows the Heteša, Marvan (2006) methodology; for macrophytes the Grulich, Vydrová (2006) method; and the Liška (2007) methodology for the contamination of river ecosystems by specific inorganic and organic substances using bioindicator organisms.

Several survey methods were tested and applied in Czechia for hydromorphological monitoring. The ecohydromorphological monitoring after the River Habitat quality method - EcoRivHab (Matoušková 2003, 2007) as presented 

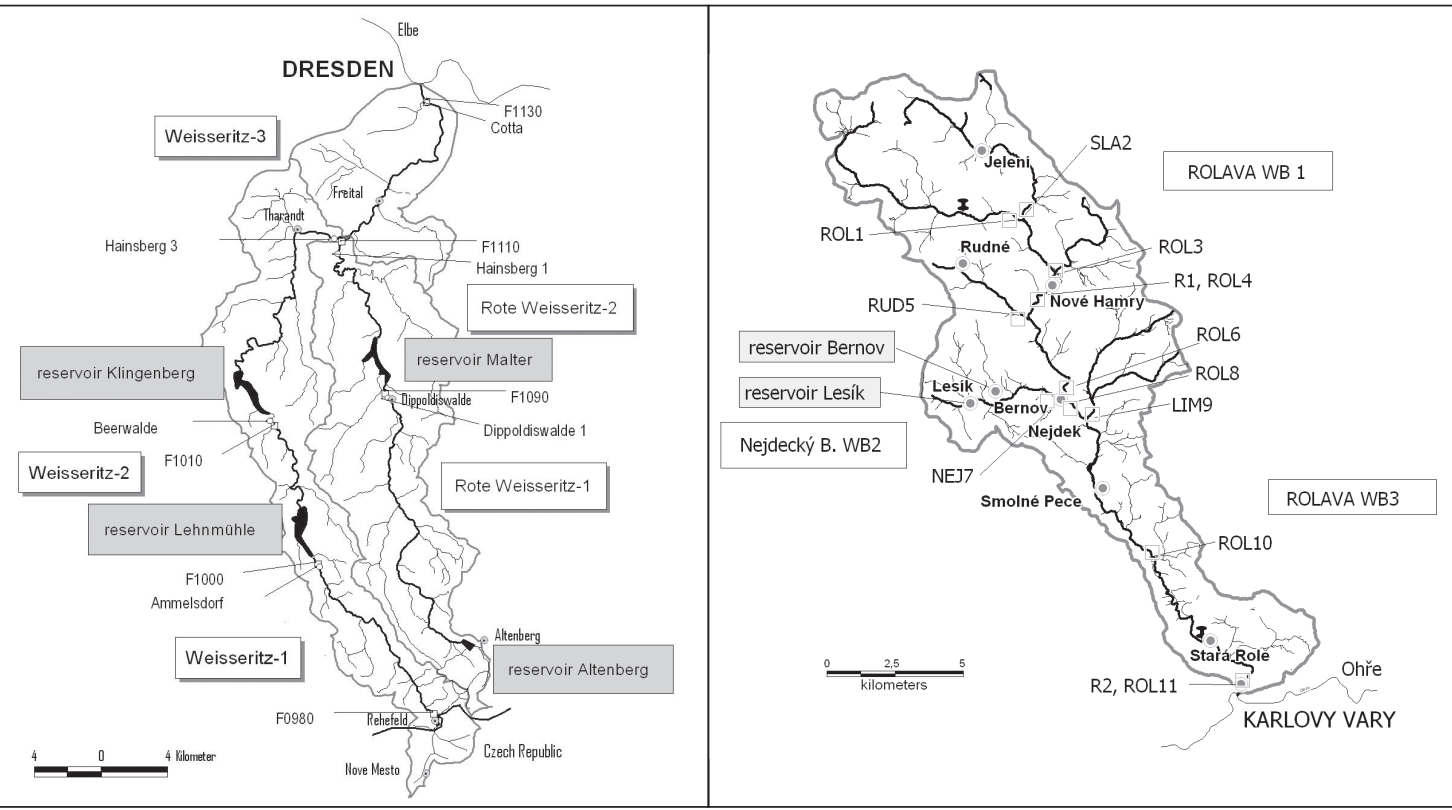

Fig. 1 - Weisseritz River basin (a) and Rolava River basin (b) in the Erzgebirge / Krušné Hory

here, was used to map approximately 500 river $\mathrm{km}$ from 2003 to 2007 in the Czech part of the Elbe River basin. The Hydroecological Monitoring method HEM (Langhammer 2007) was recommended as a standard method for hydromorphological surveying by the Ministry of Environment in the Czech Republic in 2008.

\section{Case study areas and data sources}

\subsection{Case study areas}

The study areas are situated in the Erzgebirge / Krušné hory, a Central European mountain range along the border between Saxony (Germany) and Bohemia (Czechia, Fig. 1). The Weisseritz river basin flows through the eastern part of the mountains (Fig. 1a). It extends from Czechia in the south (909 m a.s.l.) to the Elbe river at the city of Dresden in the north (107 m a.s.l.). The river basin of the Rolava is located in the western part of the mountains in the northwest of Czechia (Fig. 1b). Its northern part lies in Germany (920 m a.s.l.). In the south it discharges into the Ohře River at Karlovy Vary (370 m a.s.l.).

\subsection{Weisseritz catchment}

The river basin is subdivided into Rote (Red), Wilde (Wild), and Vereinigte (United) Weisseritz (Fig. 1a). It is part of the European ecoregion 9 - Central 
Tab. 2 - Specification of water bodies in the Weisseritz catchment (LfUG 2007)

\begin{tabular}{|lllll|}
\hline Water body name & Short name & Ident-No. & Stream & Category \\
\hline $\begin{array}{l}\text { Divoká Bystřice } \\
\text { (Weisseritz-1) }\end{array}$ & W-1 & DESN_5372-1 & $\begin{array}{l}\text { Wild up to reservoir } \\
\text { Lehnmuehle }\end{array}$ & natural \\
\hline Weisseritz-2 & W-2 & DESN_5372-2 & $\begin{array}{l}\text { Wild between reser- } \\
\text { voirs Lehnmuehle } \\
\text { and Klingenberg }\end{array}$ & natural \\
\hline Weisseritz-3 & W-3 & DESN_5372-3 & $\begin{array}{l}\text { Wild up to conflu- } \\
\text { ence with Red, } \\
\text { and United up to } \\
\text { confluence with } \\
\text { Elbe river }\end{array}$ & natural \\
\hline Rote Weisseritz-1 & RW-1 & DESN_53722-1 & $\begin{array}{l}\text { Red up to reservoir } \\
\text { Malter }\end{array}$ & heavily modi- \\
fied
\end{tabular}

Highlands, and its lithology is dominated by gneissic, granitic and porphyric bedrock. The waters belong to the German bio-coenotically relevant siliceous highland streams and rivers (Pottgiesser, Sommerhäuser 2004). The drainage area covers about $384 \mathrm{~km}^{2}$ with an elevation difference of $798 \mathrm{~m}$, and a total river length $102 \mathrm{~km}$. Average flow velocities were around $0.5 \mathrm{~m} . \mathrm{sec}^{-1}$. Run-off characteristics are strongly influenced by precipitation storage as snow and by snow melt and summer rains. The related discharge regime was characterized by flood events in winter and spring, with peaks between February and April. A secondary peak was observed in July/August and corresponded to extreme precipitation events and thunder storms, e.g., the major flood event in August 2002.

The Wilde Weisseritz develops in Czechia near Nové Město. It is dammed further downstream by the two reservoirs Lehnmühle and Klingenberg. Both supply drinking water for Dresden and Freital, serve flood protection and hydro-energy. Compared to the Rote Weisseritz, the immediate vicinity of the river is almost uninhabited, except for the towns of Tharandt and Freital. Smaller settlements are located in side valleys or on the valley slopes and affect the river only locally. The source of the Rote Weisseritz lies close to the towns of Altenberg and Zinnwald-Georgenfeld (Cínovec) at the Czech-German border. The river is dammed by the Malter reservoir, serving flood protection, industrial water supply, energy production, and local recreation. Fiftyfive percent of the river course is strongly influenced by settlements within the floodplain, river straightening and maintenance for flood protection. Only the upper reaches downstream from the Altenberg reservoir, and the lower reaches between the Malter dam and the city of Freital remain largely unaffected by human activities (nature conservation areas). Both Weisseritz rivers converge in Freital to form the Vereinigte Weisseritz. The remaining stretch downstream to the Elbe River is significantly influenced by urban settlement. The three main rivers are subdivided into five water bodies (Table 2). RW-1 was categorized to be a heavily modified water body, the others are natural (LfUG 2007). 


\subsection{Rolava catchment}

The Rolava source is located in the Czech-German border region on the Krušné hory plateau. The catchment is part of the European ecoregion 9 Central Highlands, and its lithology is dominated by granite, gneiss, mica schist. The river basin covers an area of $138 \mathrm{~km}^{2}$ (Fig 1b). The length of the main stream is $36.6 \mathrm{~km}$. The mean daily discharge was $2.39 \mathrm{~m}^{3} \cdot \mathrm{sec}^{-1}$. The water basin is characterized by variable runoff with relatively frequent flooding. The largest runoff typically occurs in April and March, due to snowmelt. The catchment is subdivided into three water bodies (Table 3). WB-1 was categorized as natural, the others are heavily modified.

Tab. 3 - Specification of water bodies in the Rolava catchment

\begin{tabular}{|lllll|}
\hline Water body label & Ident-No. & Name & Stream & Category \\
\hline WB1 & 14121000 & $\begin{array}{l}\text { Rolava River up } \\
\text { to confluence with } \\
\text { Nejdecký Brook }\end{array}$ & Rolava & natural \\
\hline WB2 & 14122000 & Nejdecký Brook & Nejdecký Brook & heavily modified \\
\hline WB3 & 14125000 & $\begin{array}{l}\text { Rolava River up } \\
\text { to confluence with } \\
\text { Ohře River }\end{array}$ & Rolava & heavily modified \\
\hline
\end{tabular}

The upper stream runs through the flat, forest-free terrain of the nature reserve Přebuz with large peat bogs, important for water retention. The middle course of the Rolava changes into a wilder mountain forest stream with a riverbed of stones or even boulders and steep slopes. Thereafter, the stream runs through urbanized areas of the village Nové Hamry and Nejdek city. The slope ratio slowly decreases downstream, where the Rolava passes through Nová Role and Karlovy Vary city. From the water management point of view, only the small reservoirs Lesík and Bernov, located on the Nejdecký brook, are noteworthy. The population density in the Rolava catchment is low, particularly in the northern part (611 inhabitants). In total, 35,000 people inhabited the area in 2001. Most of them live downstream in Karlovy Vary (53,358 inhabitants, only partly in Rolava catchment). Due to the frequent occurrence of flood discharge, flood protection measures have been taken. River channel alterations are also associated with the construction of small water power stations and roads (Weiß et al. 2008).

\subsection{Data source Weisseritz catchment}

Hydrobiological and hydrochemical monitoring data are collected by the Saxon State Authority of Environment, Agriculture and Geology (LfULG). This authority maintained a network of twenty major measurement points ( $\mathrm{F}$ points) and six points for occasional waste water input control (SA points) in the three Weisseritz rivers until operative monitoring started in 2006. These numbers were reduced to seven measurement points (OBF points) for operative monitoring, i.e., one or two per water body. Five points are additionally 
Tab. 4 - Selected monitoring points of Saxon State Authority at the Weisseritz rivers. Data source: LfULG, correspondence with A. Biemelt, 6.2.2003 and K. Ziegler, 30.6.2004, corresponding water body and stream type

\begin{tabular}{|llccccc|}
\hline Points & Location & Flow km & Longitude & Latitude & $\begin{array}{c}\text { Water } \\
\text { body }\end{array}$ & $\begin{array}{c}\text { Stream } \\
\text { type }\end{array}$ \\
\hline F0980 & $\begin{array}{l}\text { Czech-German } \\
\text { border (Wild) }\end{array}$ & 44.8 & 5621880 & 5408900 & W-1 & 5 \\
\hline F1000 & $\begin{array}{l}\text { above reservoir } \\
\text { Lehnmuehle (Wild) }\end{array}$ & 32.1 & 5630820 & 5402000 & W-1 & 5 \\
\hline F1010 & $\begin{array}{l}\text { above reservoir } \\
\text { Klingenberg (Wild) }\end{array}$ & 21.3 & 5639100 & 5399380 & W-2 & 5 \\
\hline F1130 & mouth (United) & 1.2 & 5658420 & 5408450 & W-3 & 9 \\
\hline F1090 & $\begin{array}{l}\text { above reservoir } \\
\text { Malter (Red) }\end{array}$ & 13.4 & 5640990 & 5406000 & RW-1 & 5 \\
\hline F1110 & mouth (Red) & 0.5 & 5650080 & 5403400 & RW-2 & 9 \\
\hline
\end{tabular}

used to practically test the new hydrobiological investigation and assessment methods.

Monitoring data presented in this paper were supplied by the LfULG, based on co-operation agreement within the interdisciplinary EMTAL-project (Catchment Management of Reservoirs in Mountainous Regions; Matschullat et al. 2005; Weiß et al. 2003). This project ran between 2002 and 2007, focussing on water quality related issues from 1992 to 2003 (Bernatowicz et al. 2008). The year 2001 and the six points were selected to represent the five Weisseritz water bodies (Table 4). These points are used since 2006.

Lack of data availability and quality, and high variations in sampling frequencies between years and sites had already been discussed (e.g., Bernatowicz et al. 2008; Weiß 2007). Sampling density was highest in 2001, and all sites were investigated for the first time since 1992 (hydrobiology: 2-4 measurements per year and site, hydrochemistry - basic programme inorganic components: $12-13$ measurements per year and site). The following years 2002/2003 are under-represented by data because of the flood event in August 2002 and the reconstruction and river engineering activities thereafter. Even for 2001 the hydrobiological and hydrochemical monitoring data do not meet the new WFD sampling and assessment methods. Therefore, the data can only be used for an ecological status estimate (Weiß 2007).

Hydrobiological monitoring focused on benthic macroinvertebrates, stream type, and stressor specific assessment. After removing some taxonomic mistakes in the original benthic macroinvertebrate taxa lists of LfULG, data were standardized to the level of the Operational Taxa List (Haase et al. 2004), and tested with the AQEM software Version 2.5 (AQEM Consortium 2005). Since samples were taken after DIN 38410 (DEV 1992), abundance classes (Alf et al. 1992) were available instead of data on individuals per $\mathrm{m}^{-2}$. The abundance classes were transformed into number of individuals, using class mean values (Meier et al. 2006). The AQEM official German system method was applied to estimate the effects of the stressors organic pollution, acidification and general degradation on benthic macroinvertebrates, and to 
describe the benthic community by taxonomic composition, number of taxa, and abundance.

Hydrochemical monitoring was based on basic physico-chemical parameters (e.g., temperature, dissolved oxygen, chloride, $\mathrm{P}_{\text {tot }}, 0-\mathrm{PO}_{4}-\mathrm{P}, \mathrm{NH}_{4}-\mathrm{N}, \mathrm{pH}-$ value, $\mathrm{COD}$, conductivity) to support the interpretation of the hydrobiological data. The assessment of the LfULG-data was done according to the streamtype specific background and orientation values (LAWA 2007; Table 1), and completed with the common parameters DOC, COD and conductivity (without classification). The LAWA preliminary specification uses the following statistical values: mean for TOC, $\mathrm{BOD}_{5}$, chloride, $\mathrm{P}_{\text {tot }}, 0-\mathrm{PO}_{4}-\mathrm{P}, \mathrm{NH}_{4}-\mathrm{N}$, seasonal variability for temperature and dissolved oxygen, and minimum and maximum for $\mathrm{pH}$-value.

Hydromorphological data analysed here were collected during spring and summer 2003, and updated in 2005 (Weiß 2004, 2005, 2007; Weiß et al. 2008), using the field method (LAWA 2000). The official data from the application of the German overview method (LAWA 2002), used for the first analysis of the river basins in Saxony to the end of 2004, did not fulfil the WFD-criteria for evaluating hydromorphological conditions (Weiß 2007; Weiß et al. 2008). The LfULG-field mapping programme of all Saxon running waters with a catchment area $>10 \mathrm{~km}^{2}$ was done between 2005 and 2008. The Weisseritz rivers were mapped, e.g., in 2006/2007, and results were available at the end of 2008 (correspondence with Dr. F. Herbst, LfULG, 11.12.2008). River continuity is evaluated by the number of impassable artificial barriers (weirs, crossings) that disturb the migration of aquatic organisms and sediment transport. Field mapping was mainly done during the stream habitat survey, and completed in 2004/2005. The classification followed LAWA (2000), the assessment of continuity focussed on fish fauna (Weiß 2007). Runoff data of the gauging stations Ammelsdorf (W-1; 33,3 flow km), Beerwalde (W-2; 21.5 flow km), Hainsberg 3 (W-3; 0.9 flow km), Cotta (W-3; flow km 1,2), Hainsberg 1 (RW-1; 15,2 flow km) and Dippoldiswalde 1 (RW-2; 1.5 flow km; Fig. 1a) were used to explain the hydrological regime in the Weisseritz rivers. Special attention is given to the flood event in August 2002 and the low water period in summer 2003.

\subsection{Data source Rolava catchment}

Water samples from eleven profiles (Table 5) were analyzed for 2006-2007. Analysis was done in the laboratories of the Institute for Environmental Studies, Faculty of Science, Charles University. Samples for chemical analysis were taken three times a year. At the same time, macroinvertebrate samples were taken in three selected profiles (ROL1 WB1, ROL6 WB1, ROL11 B WB 3) in the main stream of Rolava River (Table 5) in summer 2006; and in autumn and spring 2007). Samples were taken with the kicking method (Kokeš et al. 1999 in Hryzáková 2008).

Terrain monitoring in 2005-2006 was used as the data source for the hydromorphological investigation. Mapping was done after EcoRivHab and LAWA-FS (Lelut 2007; Lelut, Matoušková 2008). Migration barriers were recorded as part of the ecohydromorphological mapping. Qd values (average daily discharges) from two water gauging stations situated on the Rolava River 
Tab. 5 - Monitoring points of the Charles University hydrochemical survey in the Rolava catchment

\begin{tabular}{|c|c|c|c|c|c|c|}
\hline Points & Location & $\begin{array}{c}\text { Flow } \\
\text { km }\end{array}$ & $\begin{array}{l}\text { Hydro- } \\
\text { chemical } \\
\text { survey }\end{array}$ & $\begin{array}{c}\text { Macro- } \\
\text { inverte- } \\
\text { brates }\end{array}$ & Longitude & Latitude \\
\hline ROL1 WB1 & Upper Rolava & 25.1 & yes & yes & N50²2'31" & $\mathrm{E} 12^{\circ} 41^{\prime} 52^{\prime \prime}$ \\
\hline SLA2 WB1 & Slatinný Brook & 25.0 & yes & no & N50²2'33" & $\mathrm{E} 12^{\circ} 41^{\prime} 55^{\prime \prime}$ \\
\hline ROL3 WB1 & Rolava above Nové Hamry & 24.1 & yes & no & N50²2'02" & $\mathrm{E} 12^{\circ} 42^{\prime} 12^{\prime \prime}$ \\
\hline ROL4 WB1 & Rolava below Nové Hamry & 22.0 & yes & no & N50²1'17" & $\mathrm{E} 12^{\circ} 43^{\prime} 03^{\prime \prime}$ \\
\hline RUD5 WB1 & Rudenský Brook & 20.1 & yes & no & N50²0'39" & $\mathrm{E} 12^{\circ} 42^{\prime} 25^{\prime \prime}$ \\
\hline ROL6 WB1 & Rolava above Nejdek & 19.0 & yes & yes & N5020' $16^{\prime \prime}$ & $\mathrm{E} 12^{\circ} 42^{\prime} 53^{\prime \prime}$ \\
\hline NEJ7 WB2 & Nejdecký Brook & 16.7 & yes & no & N50¹9'16" & $\mathrm{E} 12^{\circ} 43^{\prime} 11^{\prime \prime}$ \\
\hline ROL8 WB3 & Rolava - STP Nejdek & 16.2 & yes & no & N5018'51" & $\mathrm{E} 12^{\circ} 44^{\prime} 40^{\prime \prime}$ \\
\hline LIM9 WB3 & Limnice & 15.4 & yes & no & N5019'08" & $\mathrm{E} 12^{\circ} 44^{\prime} 57^{\prime \prime}$ \\
\hline ROL10 WB3 & Rolava - STP Nová Role & 8.0 & yes & no & N5016'11" & $\mathrm{E} 12^{\circ} 47^{\prime} 35^{\prime \prime}$ \\
\hline ROL11 WB3 & Rolava - Stará Role & 4.0 & yes & no & N5014'55" & $\mathrm{E} 12^{\circ} 49^{\prime} 12^{\prime \prime}$ \\
\hline ROL11B WB3 & & 4.8 & no & yes & & \\
\hline
\end{tabular}

(Chaloupky - 27.9 flow $\mathrm{km}$ ) in the upper stream and Stará Role in the lower stream (3.84 flow km - Fig. 1b) were used as primary data for hydrological assessment. The data were provided by the Czech Hydrometeorological Institute (CHMI) and covered the period from Nov 1, 1966 to Oct 31, 2007 for Chaloupky (Nr. 2091), and from Oct 1, 1968 to Oct 31, 2007 (with a gap from Aug 1, 2004 to Oct 31, 2005) for Stará Role (Nr. 2101).

\section{Results}

\subsection{Weisseritz River Basin}

Hydrobiological data. The benthic invertebrate community consisted of 71 species and taxonomic groups. The five water bodies yielded the following species numbers: i) W-1: 47; ii) W-2: 33; iii) W-3: 22; iv) RW-1: 20; v) RW-2: 28. Biota were dominated by insecta (ca. 90\%), represented by Ephemeroptera (6-10 species), Plecoptera (1-12 species), Trichoptera (4-9 species), Diptera (4-6 species), Coleoptera (2-5 species) and Megaloptera (1 species) in all water bodies (Fig. 2). Crustacea, Gastropoda, Oligochaeta, Hirudinea, Bivalvia and Acari occurred with one or two species.

The ecological status of the water bodies can be estimated during the year 2001 to be good, moderate or poor, dependent on the measurement point (Tab. 6). Organic pollution was of minor significance at all points (good status). Acidification was relevant for the stream type 5 water bodies only. Acidification was not a serious problem in 2001, as compared to other years (Weiß 2007). Even the results for the four samples in the Wilde Weisseritz headwater (near Rehefeld) showed a frequently good status for the stressor acidification. That point near the German-Czech border had the best ecological quality in the entire river basin jointly with the good status estimate for the stressor "general degradation". This stressor mainly indicates impacts of morphological degradation and land use in the catchment area. Furthermore, it can be a result 
Tab. 6 - Stream type specific estimation of the ecological status at the Weisseritz rivers based on benthic macroinvertebrates. Data source: LfULG, correspondence with A. Biemelt, 6.2.2003; Year: 2001; Software: AQEM Version 2.5; worst case principle for overall Ecological Quality Class; QC = Quality Class.

\begin{tabular}{|c|c|c|c|c|c|c|}
\hline Point & $\begin{array}{l}\text { Water } \\
\text { body }\end{array}$ & $\begin{array}{l}\text { Samples } \\
\text { (Year 2001) }\end{array}$ & $\begin{array}{c}\mathrm{QC} \\
\text { Organic } \\
\text { pollution }\end{array}$ & $\begin{array}{l}\text { QC Acidifi- } \\
\text { cation }\end{array}$ & $\begin{array}{c}\mathrm{QC} \\
\text { General } \\
\text { degradation }\end{array}$ & $\begin{array}{c}\text { Ecological } \\
\text { Quality } \\
\text { Class }\end{array}$ \\
\hline F0980 & $\mathrm{W}-1$ & 12.2./2.8./2.10./10.12. & good & good & good & good \\
\hline F1000 & $\mathrm{W}-1$ & $12.2 . / 2.8$ & good & good & moderate & moderate \\
\hline F1010 & $\mathrm{W}-2$ & 12.2./2.8 & good & good & moderate & moderate \\
\hline F1130 & $\mathrm{W}-3$ & 6.6./2.8. & good & not relevant & moderate & moderate \\
\hline F1090 & RW-1 & 22.2./11.7. & good & good & poor & poor \\
\hline F1110 & RW-2 & 22.2./11.7. & good & not relevant & moderate & moderate \\
\hline
\end{tabular}

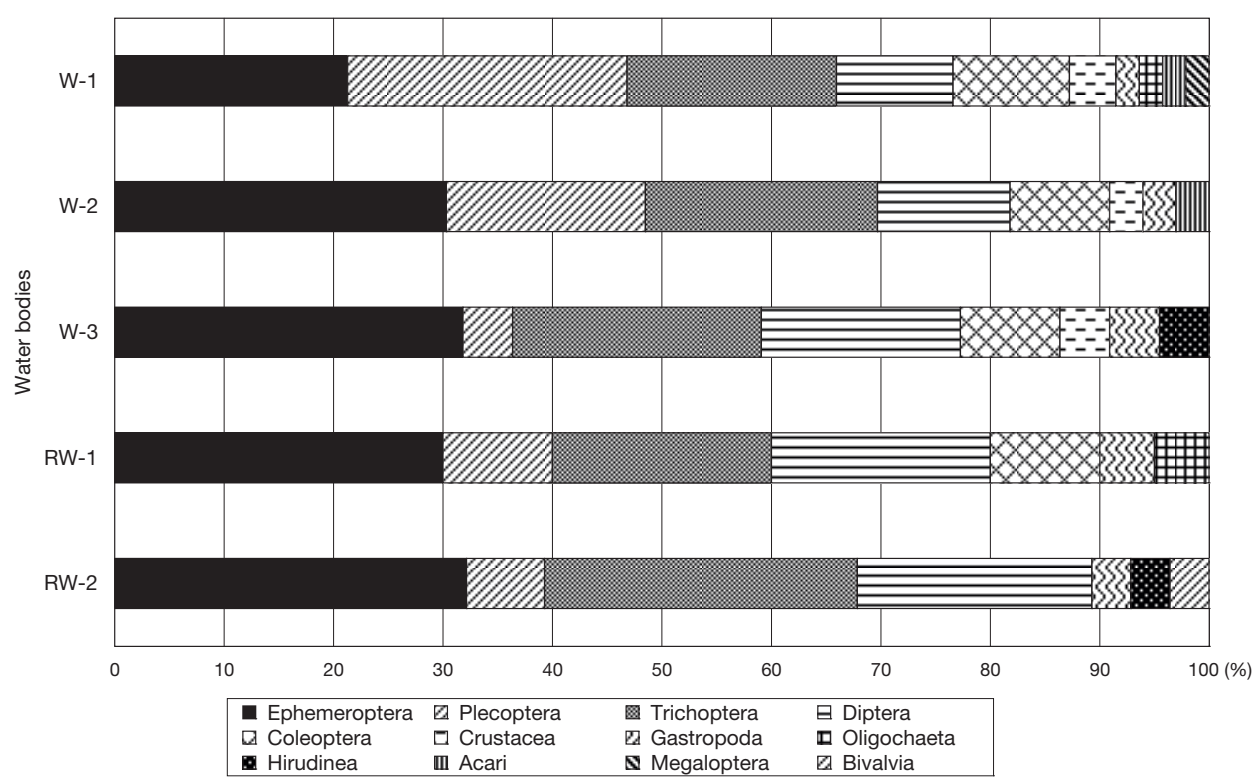

Fig. 2 - Composition of benthic invertebrate fauna in the Weisseritz water bodies based on taxonomic groups. Data source: LfULG, correspondence with A. Biemelt, 06.02.2003; Year: 2001.

of altered hydrological regimes by off-takes, releases from dams and backwater (e.g., artificial barriers, weirs, water transfer) or chemical pollutants. The benthic invertebrate fauna confirms the low anthropogenic influence. Number of species and their composition show stream type specific conditions as compared to similar siliceous highland streams. Further downstream, the benthic invertebrate fauna is characterized by a reduction in species composition and abundance. Here, the estimation of the stressor "general degradation" is decisive for the ecological quality class (worst-case principle): moderate status for water bodies Weisseritz - 2, Weisseritz - 3 and Rote Weisseritz - 2, and poor status for Rote Weisseritz - 1 (6). 
Tab. 7 - Hydrochemical status estimation of the Weisseritz rivers based on the parameters of the LAWA background and orientation values (LAWA 2007) and other common parameters. Data source: LfULG, correspondence with K. Ziegler, 30.6.2004; Year: 2001; italic - differs from background values, bold italic - differs from orientation values.

\begin{tabular}{|c|c|c|c|c|c|c|c|c|}
\hline $\begin{array}{l}\text { Parameters } \\
\text { (LAWA } \\
\text { 2007) }\end{array}$ & Units & $\begin{array}{l}\text { Statistic } \\
\text { value }\end{array}$ & $\begin{array}{l}\text { F0980 } \\
\text { (W-1) }\end{array}$ & $\begin{array}{l}\text { F1000 } \\
(\mathrm{W}-1)\end{array}$ & $\begin{array}{l}\text { F1010 } \\
(\mathrm{W}-2)\end{array}$ & $\begin{array}{l}\text { F1130 } \\
\text { (W-3) }\end{array}$ & $\begin{array}{l}\text { F1090 } \\
\text { (RW-1) }\end{array}$ & $\begin{array}{c}\text { F1110 } \\
\text { (RW-2) }\end{array}$ \\
\hline $\begin{array}{l}\text { Tempera- } \\
\text { ture }\end{array}$ & ${ }^{\circ} \mathrm{C}$ & $\min -\max$ & $0.3-12.8$ & $0.1-13.4$ & $0.1-11.0$ & $1.3-16.7$ & $-0.1-15.1$ & $1.5-15.1$ \\
\hline $\begin{array}{l}\text { Oxygen } \\
(\text { at tempera- } \\
\left.\text { ture, }{ }^{\circ} \mathrm{C}\right)\end{array}$ & $\mathrm{mg} / \mathrm{l}$ & $\min -\max$ & $\begin{array}{c}9.5(12.8) \\
-12.7 \\
(2.3)\end{array}$ & $\begin{array}{c}9.3(13.4) \\
-12.7 \\
(0.1 ; 3.0)\end{array}$ & $\begin{array}{c}10.1(10.7) \\
-13.3(0.1)\end{array}$ & $\begin{array}{c}9.4(16.7) \\
-12.7 \\
(4.1)\end{array}$ & $\begin{array}{c}9.2(15.1) \\
-13.8 \\
(-0.1)\end{array}$ & $\begin{array}{c}9.2(14.0) \\
-12.9 \\
(1.5)\end{array}$ \\
\hline Chloride & $\mathrm{mg} / \mathrm{l}$ & mean & 3.2 & 7.5 & 8.3 & 41 & 20 & 23 \\
\hline $\mathrm{P}_{\text {tot }}$ & $\mathrm{mg} / \mathrm{l}$ & mean & 0.023 & 0.052 & 0.026 & 0.18 & 0.063 & 0.16 \\
\hline $0-\mathrm{PO}_{4}-\mathrm{P}$ & $\mathrm{mg} / \mathrm{l}$ & mean & 0.018 & 0.018 & 0.018 & 0.12 & 0.027 & 0.12 \\
\hline $\mathrm{NH}_{4}-\mathrm{N}$ & $\mathrm{mg} / \mathrm{l}$ & mean & 0.043 & 0.051 & 0.055 & 0.14 & 0.15 & 0.18 \\
\hline TOC & $\mathrm{mg} / \mathrm{l}$ & mean & 5.9 & 4 & 3.2 & 4.8 & 4.4 & 4.8 \\
\hline $\begin{array}{l}\text { pH-value } \\
(\mathrm{lab})^{*}\end{array}$ & & $\min -\max$ & $5.3-6.7$ & $6.4-7.0$ & $6.4-6.9$ & $7.0-7.8$ & $6.2-7.0$ & $6.8-7.3$ \\
\hline \multicolumn{9}{|l|}{ Others } \\
\hline $\begin{array}{l}\text { Conductivity } \\
\left(25^{\circ} \mathrm{C}\right)\end{array}$ & $\mu \mathrm{S} / \mathrm{cm}$ & $\min -\max$ & $50-102$ & $82-164$ & $93-203$ & $251-870$ & $158-256$ & $195-460$ \\
\hline $\begin{array}{l}\text { Conductivity } \\
\left(20^{\circ} \mathrm{C}\right)\end{array}$ & $\mu \mathrm{S} / \mathrm{cm}$ & $\min -\max$ & $45-91$ & $73-147$ & $83-182$ & $225-780$ & $142-229$ & $175-412$ \\
\hline COD & $\mathrm{mg} / \mathrm{l}$ & mean & 13 & 9 & 7 & 13 & 9 & 11 \\
\hline $\mathrm{N}-\mathrm{NO}_{3}$ & $\mathrm{mg} / \mathrm{l}$ & mean & 1.0 & 2.3 & 3.6 & 3.9 & 5.1 & 5.9 \\
\hline $\begin{array}{l}\text { Acidity } \\
(4,3)\end{array}$ & $\mathrm{mol} / \mathrm{l}$ & mean & 0.13 & 0.31 & 0.27 & 0.26 & 0.59 & 1.2 \\
\hline $\begin{array}{l}\text { Alkalinity } \\
(8,2)\end{array}$ & $\mathrm{mmol} / \mathrm{l}$ & mean & 0.047 & 0.034 & 0.029 & 0.036 & 0.029 & 0.027 \\
\hline
\end{tabular}

* Authors are aware of possible inaccuracy caused by measurement in laboratory

Hydrochemical data (physico-chemical elements). In 2001, temperature, oxygen, chloride, $\mathrm{NH}_{4}-\mathrm{N}$ and TOC corresponded to the orientation values at all points (Tab. 7). These values were exceeded by $\mathrm{P}_{\text {tot }}$ and $0-\mathrm{PO}_{4}-\mathrm{P}$ in the lower reaches of Rote Weisseritz (RW-2) and Vereinigte Weisseritz (W-3). Minimum $\mathrm{pH}$-values (laboratory measurement) were lower than the orientation values in the upper and middle reaches of Wilde Weisseritz (W-1, W-2) and the upper reaches of the Rote Weisseritz (RW-1). BOD5 was not detected.

The status of the biological component benthic macroinvertebrates was evaluated to be "not good" at five of the six points (excluding F0980). Based on the comparison with the orientation values, the parameters $\mathrm{pH}$-value, $\mathrm{P}_{\text {tot }}$ and o- $\mathrm{PO}_{4}-\mathrm{P}$ can be identified to represent possible pressures. The stressor specific bio-assessment showed a good status with regard to acidification at stream type 5 reaches (F0980, F1000, F1010, F1090). This indicates that the $\mathrm{pH}$-value was no stressor in 2001. The same was true for the nutrients $\mathrm{P}_{\text {tot }}$ and o- $\mathrm{PO}_{4}-\mathrm{P}$, since the bio-assessment showed a good status with regard to organic pollution. In the water bodies W-2, W-3, RW-2 and RW-1 the moderate or poor 
Tab. 8 - River continuity and morphological conditions in the Weisseritz river basin. Data source: Field mapping by LAWA-field survey method during 2003-2005. Morphology: total of 907 sections, WFD-classification system; for details see Weiß 2004, 2005, 2007.

\begin{tabular}{|l|c|c|c|c|c|c|c|}
\hline \multirow{2}{*}{$\begin{array}{l}\text { Water } \\
\text { body }\end{array}$} & $\begin{array}{c}\text { River } \\
\text { continuity }\end{array}$ & \multicolumn{6}{|c|}{ Morphological conditions } \\
\cline { 2 - 8 } & $\begin{array}{c}\text { Impassable } \\
\text { cross-structures }\end{array}$ & $\begin{array}{c}\text { Class 1 } \\
\%\end{array}$ & $\begin{array}{c}\text { Class 1 } \\
\%\end{array}$ & $\begin{array}{c}\text { Class 1 } \\
\%\end{array}$ & $\begin{array}{c}\text { Class 1 } \\
\%\end{array}$ & $\begin{array}{c}\text { Class 1 } \\
\%\end{array}$ & $\begin{array}{c}\text { Overall } \\
\text { Status }\end{array}$ \\
\hline W-1 & 10 & 5 & 19 & 47 & 26 & 4 & moderate \\
W-2 & 5 & 1 & 24 & 39 & 30 & 6 & moderate \\
W-3 & 11 & 4 & 10 & 14 & 22 & 50 & bad \\
RW-1 & 17 & 0 & 7 & 21 & 34 & 38 & bad \\
RW-2 & 8 & 3 & 23 & 30 & 29 & 16 & moderate \\
\hline
\end{tabular}

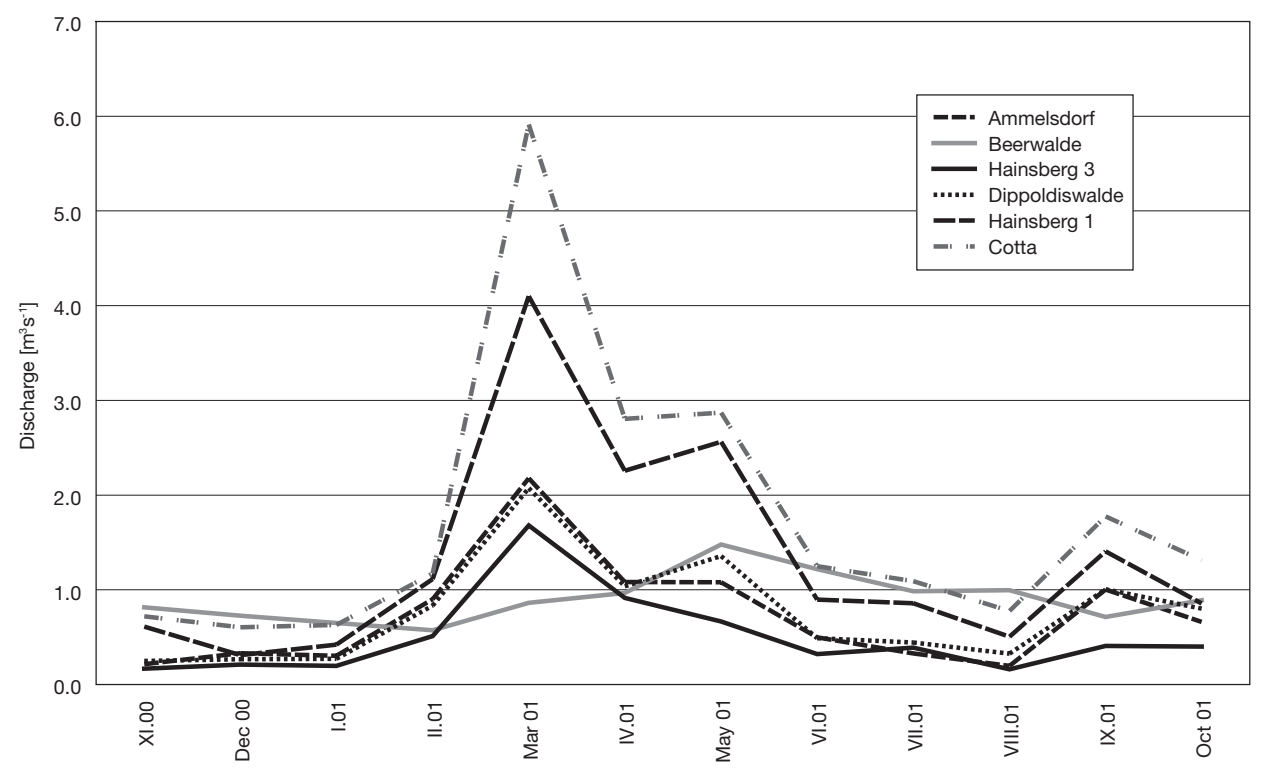

Fig. 3 - Discharge at selected gauging stations of the Weisseritz rivers in the hydrological year 1.11.2000-31.10.2001. Data source: StUFA Radebeul, correspondence with Dr. A. Barth, Beak Consultants GmbH, 02.08.2004; monthly mean based in daily means.

status estimation of the stressor general degradation (Tab. 6, 9) is decisive for the ecological quality class.

Hydromorphological data. Run-off characteristics are strongly influenced by precipitation storage as snow and by snow melt and summer rains. During the hydrological year 2001, the related hydrological regime was characterized by flood events in winter and spring, with peaks in March (snow melt). A secondary peak was observed in September, except for Beerwalde and Hainsberg 3. To evaluate the water flow quantities, the monthly minimum and maximum discharge values to the monthly discharge main values were compared (LfUG $2002 b$ ). Discharge fluctuated between $>$ NQ (month) and $>$ MHQ (month). The highest discharge was detected in March at all gauging station. Seasonal and 
Tab. 9 - Hydrochemical status estimation of the Rolava River catchment, based on the parameters of the LAWA background and orientation values (LAWA 2007) and other common parameters. Data source: Charles University Prague Monitoring, 2005-2007; italic - differs from background values, bold italic - differs from orientation values.

\begin{tabular}{|c|c|c|c|c|c|c|c|c|}
\hline Parameters & Units & $\begin{array}{l}\text { Statistic } \\
\text { value }\end{array}$ & $\begin{array}{l}\text { ROL1 } \\
\text { (WB1) }\end{array}$ & $\begin{array}{l}\text { SLA2 } \\
\text { (WB1) }\end{array}$ & $\begin{array}{l}\text { ROL3 } \\
\text { (WB1) }\end{array}$ & $\begin{array}{l}\text { ROL4 } \\
\text { (WB1) }\end{array}$ & $\begin{array}{l}\text { RUD5 } \\
\text { (WB1) }\end{array}$ & $\begin{array}{l}\text { ROL6 } \\
\text { (WB1) }\end{array}$ \\
\hline $\begin{array}{l}\text { Oxygen (at } \\
\text { temperature, } \\
{ }^{\circ} \mathrm{C} \text { ) }\end{array}$ & $\mathrm{mg} / \mathrm{l}$ & $\min -\max$ & $\begin{array}{c}6.9(7) \\
-9.9 \\
(15)\end{array}$ & $\begin{array}{l}7.1(7) \\
-9.1 \\
(14.5)\end{array}$ & $\begin{array}{c}6.8(7) \\
-9.8 \\
(14)\end{array}$ & $\begin{array}{c}7.3(7) \\
-9.6 \\
(15)\end{array}$ & $\begin{array}{c}7.3(7) \\
-9.6 \\
(15)\end{array}$ & $\begin{array}{l}7.6(6) \\
-9.7 \\
(15.5)\end{array}$ \\
\hline Chloride & $\mathrm{mg} / \mathrm{l}$ & mean & 0.74 & 0.3 & 0.35 & 0.75 & 3.57 & 1.71 \\
\hline o- $\mathrm{PO}_{4}-\mathrm{P}$ & $\mathrm{mg} / \mathrm{l}$ & mean & 0.02 & 0.02 & 0.01 & 0.01 & 0.06 & 0.02 \\
\hline $\mathrm{NH}_{4}-\mathrm{N}$ & $\mathrm{mg} / \mathrm{l}$ & mean & 0.45 & 0.41 & 0.60 & 0.47 & 0.51 & 0.46 \\
\hline pH-value (lab) & & $\min -\max$ & $4.9-5.9$ & $4.7-6.2$ & $4.9-6.3$ & $4.9-6.2$ & $5.2-6.7$ & $5.2-6.7$ \\
\hline \multicolumn{9}{|l|}{ Other } \\
\hline $\mathrm{NO}_{3}-\mathrm{N}$ & $\mathrm{mg} /]$ & & 3.45 & 3.27 & 3.27 & 3.18 & 3.62 & 3.32 \\
\hline $\begin{array}{l}\text { Conductivity } \\
\left(20^{\circ} \mathrm{C}\right)\end{array}$ & $\mu \mathrm{S} / \mathrm{cm}$ & $\min -\max$ & $\begin{array}{c}33.3- \\
44.4\end{array}$ & $\begin{array}{c}33.6- \\
47.1\end{array}$ & $\begin{array}{c}33.2- \\
41.7\end{array}$ & $\begin{array}{c}36.9- \\
47.8\end{array}$ & $\begin{array}{c}47.4- \\
72.5\end{array}$ & $\begin{array}{c}43.7- \\
70.4\end{array}$ \\
\hline COD & $\mathrm{mg} / \mathrm{l}$ & mean & 7.67 & 8.15 & 6.77 & 6.77 & 5.14 & 6.93 \\
\hline Acidity (4.3) & $\mathrm{mmol} / \mathrm{l}$ & mean & 0.11 & 0.11 & 0.12 & 0.12 & 0.16 & 0.18 \\
\hline Alkalinity $(8,2)$ & $\mathrm{mmol} / \mathrm{l}$ & mean & 0.28 & 0.41 & 0.23 & 0.29 & 0.27 & 0.23 \\
\hline Parameters & Units & $\begin{array}{l}\text { Statistic } \\
\text { value }\end{array}$ & $\begin{array}{l}\text { NEJ7 } \\
\text { (WB2) }\end{array}$ & $\begin{array}{l}\text { ROL8 } \\
\text { (WB3) }\end{array}$ & $\begin{array}{l}\text { LIM9 } \\
\text { (WB3) }\end{array}$ & $\begin{array}{l}\text { ROL10 } \\
\text { (WB3) }\end{array}$ & $\begin{array}{l}\text { ROL11 } \\
\text { (WB3) }\end{array}$ & \\
\hline $\begin{array}{l}\text { Oxygen (at } \\
\text { temperature, } \\
{ }^{\circ} \mathrm{C} \text { ) }\end{array}$ & $\mathrm{mg} / \mathrm{l}$ & $\min -\max$ & $\begin{array}{l}7.6(6) \\
-9.1 \\
(14.5)\end{array}$ & $\begin{array}{c}7.4(7) \\
-9.4 \\
(15)\end{array}$ & $\begin{array}{l}7.4(6) \\
-8.7 \\
(14)\end{array}$ & $\begin{array}{c}7.9(7.5) \\
-9.8 \\
(16)\end{array}$ & $\begin{array}{c}7.0(7.5) \\
-10.5 \\
(16)\end{array}$ & \\
\hline Chloride & $\mathrm{mg} / \mathrm{l}$ & mean & 9.47 & 6.54 & 12.27 & 8.57 & 8.51 & \\
\hline $0-\mathrm{PO}_{4}-\mathrm{P}$ & $\mathrm{mg} / \mathrm{l}$ & mean & 0.04 & 0.05 & 0.01 & 0.24 & 0.09 & \\
\hline $\mathrm{NH}_{4}-\mathrm{N}$ & $\mathrm{mg} /]$ & mean & 0.48 & 1.88 & 0.39 & 1.16 & 1.12 & \\
\hline pH-value (lab)* & & $\min -\max$ & $5.8-6.9$ & $5.5-7.0$ & $4.8-7.2$ & $6.2-7.3$ & $6.2-7.5$ & \\
\hline \multicolumn{9}{|l|}{ Other } \\
\hline $\mathrm{NO}_{3}-\mathrm{N}$ & $\mathrm{mg} / \mathrm{l}$ & mean & 6.4 & 4,77 & 4.16 & 9.05 & 8.46 & \\
\hline $\begin{array}{l}\text { Conductivity } \\
\left(20^{\circ} \mathrm{C}\right)\end{array}$ & $\mu \mathrm{S} / \mathrm{cm}$ & $\min -\max$ & $\begin{array}{l}79.8- \\
122.1\end{array}$ & $\begin{array}{l}62.8- \\
158.0\end{array}$ & $\begin{array}{l}77.4- \\
147.0\end{array}$ & $\begin{array}{l}66.0- \\
130.3\end{array}$ & $\begin{array}{l}66.3- \\
132.0\end{array}$ & \\
\hline COD & $\mathrm{mg} / \mathrm{l}$ & mean & 6.94 & 7.47 & 5.18 & 6.89 & 7.17 & \\
\hline Acidity $(4,50)$ & $\mathrm{mmol} / \mathrm{l}$ & mean & 0.34 & 0.34 & 0.25 & 0.20 & 0.26 & \\
\hline Alkalinity $(8,2)$ & $\mathrm{mmol} / \mathrm{l}$ & mean & 0.33 & 0.26 & 0.21 & 0.23 & 0.27 & \\
\hline
\end{tabular}

* Authors are aware of possible inaccuracy caused by measurement in laboratory

local fluctuations were observed for the lowest discharge. Low water periods occurred during November (Hainsberg 3), December (Hainsberg 3, Dippoldiswalde 1), January (Hainsberg 3), in August (Ammelsdorf, Hainsberg 3, Hainsberg 1), September (Hainsberg 3, Hainsberg 1), and October (Hainsberg 1). Discharge conditions at the gauging station Beerwalde differed from the others because it is located between the reservoirs Lehnmuehle and Klingenberg and strongly influenced by discharge regulation. 
The extreme hydrological and hydraulic conditions of the major flood event in August 2002 caused complete destruction of most river profiles and gauging stations. The record flood peaks were noticed on 13.8.2002, e.g., at Hainsberg 3 station with $217 \mathrm{~m}^{3} . \mathrm{s}-1$ compared to $58.9 \mathrm{~m}^{3} . \mathrm{s}-1$ (HHQ 5.7.1958) and at Hainsberg 1 station with $260 \mathrm{~m}^{3} . \mathrm{s}-1$ compared to $54.6 \mathrm{~m}^{3} . \mathrm{s}^{-1}$ (HHQ 10.7.1954).

River continuity. 124 migration barriers were mapped in the basin during 2003-2005, equal to a mean distance of $0.83 \mathrm{~km}$ between two cross-structures each (Weiß 2007). River continuity is restricted by 51 impassable cross-structures (smooth slide/ramp, high/very high fall/slope, rough slide/ramp depending on slope, height and length) higher than $0.3 \mathrm{~m}$ (Table 7).

Morphological conditions. Morphological conditions of the 907 mapped 100$\mathrm{m}$-sections were assessed to be moderately to strongly changed by human impact (WFD-classes 3 and 4). The overall morphological status was moderate for the water bodies Weisseritz-1/-2, Rote Weisseritz-2, and bad for the water bodies Weisseritz-3 and Rote Weisseritz-1 (Table 8).

The LAWA-field survey ranks $1-5 \%$ as slightly changed (LAWA-class 2), thus fulfilling WFD class 1 status. These near-natural sections mainly occur at the Wilde Weisseritz (W-1, W-2, part of W-3) and also on the lower reaches of the Rote Weisseritz (RW-2). Since unchanged flow sections do not occur at the present state, the near-natural reaches were used to define the streamspecific reference conditions for the morphological assessment. In the water body Rote Weisseritz-1, no slightly changed conditions were found. Anthropogenic impacts on morphology increased from the Wilde to the Rote Weisseritz, and were highest for the Vereinigte Weisseritz (Weiß et al. 2008). Strongly to completely changed river sections are mainly found at the Vereinigte (part of W-3) and Rote Weisseritz (W-1) due to higher influence by bank impairments, land-use, and migration barriers. Nearly the entire river channel is significantly modified at the Vereinigte Weisseritz between Freital and Dresden by bank fixation, river straightening and maintenance, and human impairments in the floodplain (Weiß et al. 2008).

\subsection{Rolava River Basin}

Hydrobiological Data. A total of 15,433 individuals were sampled in three profiles of the Upper Rolava River above the confluence point with Slatinný Brook (S. potok; ROL-I WB1), in the middle course of the Rolava above Nejdek (ROL-II WB1) and in the lower course of the Rolava - Stará Role (ROL-III WB3). Autumn samples were least represented (the lowest number of individuals and also the lowest number of determined taxa for all localities). Most individuals were taken at the beginning of June 2007. By contrast, the summer sampling in July 2006 was the richest in terms of taxa (Hryzáková 2008). The three observed profiles yielded the following number of species: (i) R-1: 37; (ii) R-2: 32; (iii) R-3: 36. Biota were dominated by insecta, represented by Diptera ( $7-8$ species), Trichoptera (5-6 species), Plecoptera (2-5 species) and Oligochaeta (3-4 species; Fig. 4).

The segment ROL-1 WB1 represents a status close to nature, with many segments of rapids of mountainous nature. Stoneflies dominated in this segment (37\%, Nemouridae and Leuctridae families). The profile ROL-2 WB1 


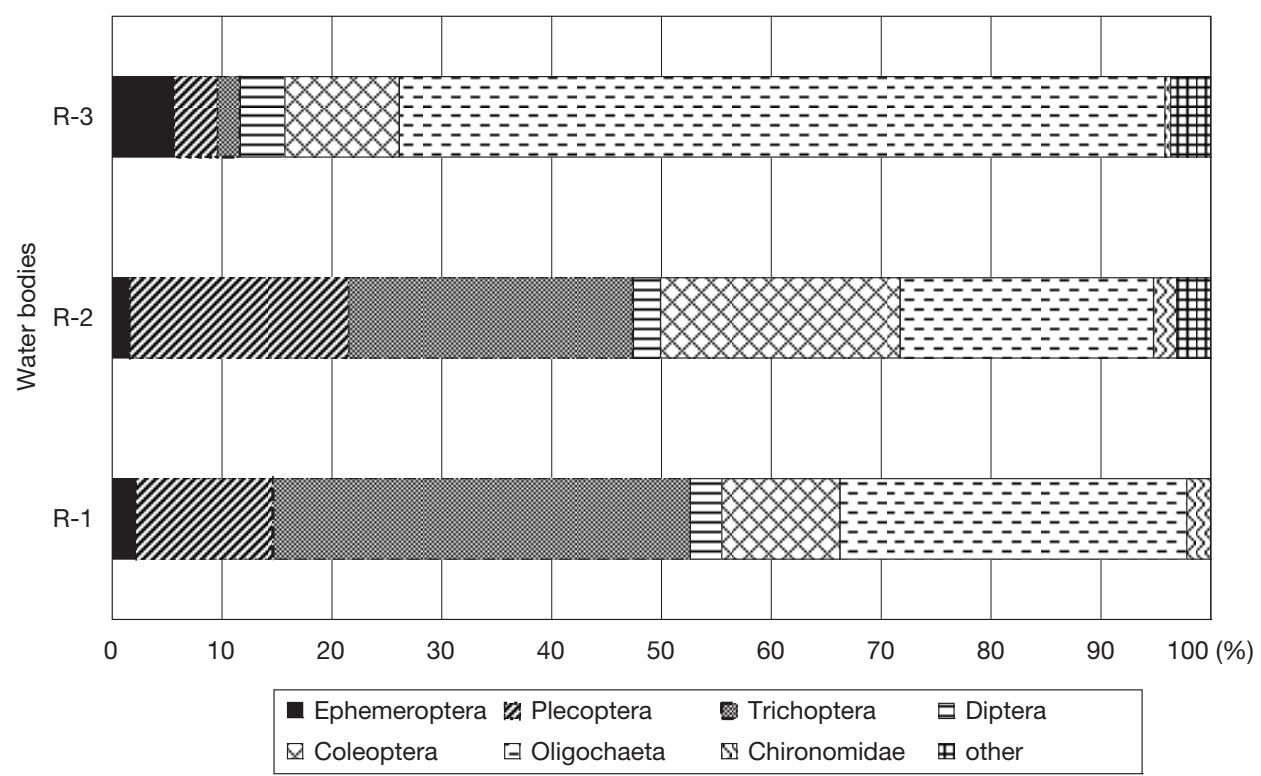

Fig. 4 - Composition of the benthic invertebrate fauna in the Rolava water bodies based on taxonomic groups. Data source: Hryzáková 2008.

was of a relatively mountainous nature (frequent segments of rapids) with similar taxa prevailing in the river, such as stoneflies of the Leuctridae and Nemouridae families (26\%). Unlike the previous profile, representation of Diptera order increased, predominantly the numbers of Ceratopogonidae, Simullidae and Pediciidae families. The profile ROL-3B WB3 is in the lower course; upstream from Karlovy Vary Town. Unlike previous profiles, ROL-3B WB3 showed a more distinct contamination by municipal and industrial water, which was also reflected in the macroinvertebrate community. Dominant taxa were predominantly represented by midge larvae (69\%). Compared to previous profiles, the numbers of stoneflies and mayflies decreased (Hryzáková, 2008).

Oxygen and chloride corresponded in the observed period with the orientation values at all points (Table 9). The concentrations of o- $\mathrm{PO}_{4}-\mathrm{P}$ exceeded the orientation values in two profiles ROL10 and ROL11 WB3. Differences were detected in $\mathrm{pH}$-values and $\mathrm{NH}_{4}^{+} \mathrm{N}$, too. High concentrations of conductivity, $\mathrm{NO}_{3}^{+}-\mathrm{N}$ and $\mathrm{NH}_{4}^{+}-\mathrm{N}$ occurred in the lower reaches of Rolava (WB3) and Nejdecký Brook (WB2).

Hydromorphological data. The mean average discharge at the upper course WR-1 (gauging station Chaloupky) is $0.72 \mathrm{~m}^{3} \cdot \mathrm{s}^{-1}$, at the lower course WR-3 (gauging station Stará Role) $2.39 \mathrm{~m}^{3} \cdot \mathrm{s}^{-1}$. Both stations reach their maximum $\mathrm{Q}_{\mathrm{ma}}$ values (long-term average monthly discharges) in April and March, relating to the snow melt. A secondary maximum value was shown in winter (e.g., December of the hydrological year 1975). $Q_{m}$ values (average monthly discharges) also show that minimum values occur during summer. This was confirmed, e.g., by the hydrological drought observed in Chaloupky in August 1975 (Ledvinka 2008). $Q_{m}$ variability is lower at Chaloupky than Stará Role. Essential increase in runoff in winter months has been seen in the Rolava 


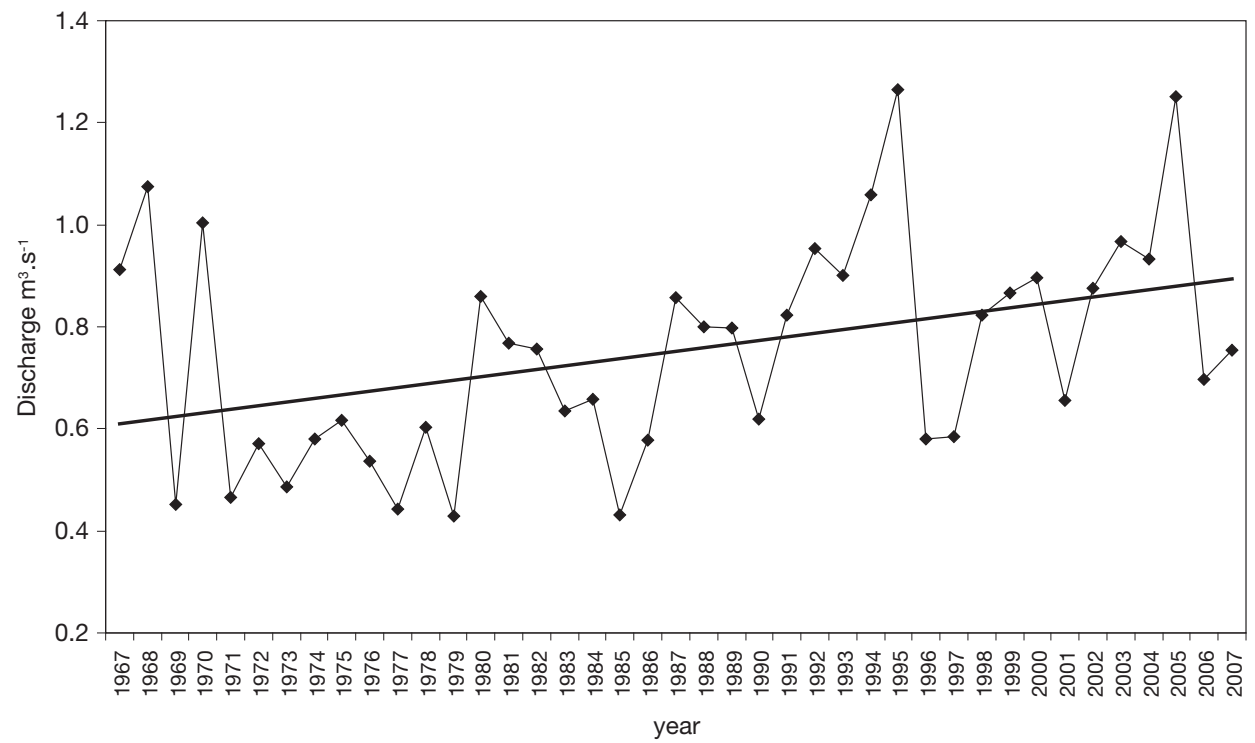

Fig. 5 - Discharge values of the Rolava River at the gauging site Chaloupky 1967-2007. Data source: CHMI Prague.

River basin since the end of the 1980's and especially in the 90's (more pronounced in the upper reaches), different in relation to the results of analyses of other mountain and foothill regions in Czechia (Kliment, Matoušková 2008). Qr variability (mean annual discharges) was higher in Chaloupky. The year 1995 had the highest water level; 2005 the second highest water level (at Chaloupky station), and 2000-2005 had significantly higher water levels still (Fig. 5).

River continuity. 29 migration barriers exceeding $0.3 \mathrm{~m}$ were mapped during the ecohydromorphological survey between 2005-2007 at Rolava River and Nejdecký Brook WB1, 2, 3; equal to a mean distance of $1.42 \mathrm{~km}$ between two barriers (Table 10). River continuity at the upper and middle course of the Rolava is restricted by small water power stations and at the lower course by weirs. The small water reservoirs Lesík and Bernov inhibit free flow at the middle and lower course of Nejdecký Brook.

Morphological conditions. The river habitat mapping was carried out using the EcoRivHab method in 2005 (Mostecká 2005), i.e., after the floods in 2002. Results were corrected and updated in January 2006 (Matoušková 2006). A direct comparison between the LAWA-FS and EcoRivHab methods was made in 2006 (Lelut 2007). The total length of the mapped river network is $72 \mathrm{~km}$. There were 99 reaches of heterogeneous length with an average length of $727 \mathrm{~m}$. The level of human impact on the Rolava can generally be described as medium. Anthropogenic impacts on morphology increased from the upper to the lower course. The highest level of anthropogenic modification was identified on the main stream of the Rolava (WB R-3). The habitat on the middle reaches of the Rolava was significantly changed where it runs through Nejdek city (class 5: $2.7 \mathrm{~km}$, WB-3). Channel and riparian belt were also significantly transformed on the lower course where the Rolava runs through Karlovy Vary 
Tab. 10 - River continuity and morphological conditions in the Rolava river basin. Data source: Field mapping by EcoRivHab field survey method during 2005-2006 (Lelut 2007); WFD-classification system; for details see Lelut (2007), Weiß et al. (2008).

\begin{tabular}{|l|c|c|c|c|c|c|c|}
\hline Water body & $\begin{array}{c}\text { River } \\
\text { continuity }\end{array}$ & \multicolumn{7}{|c|}{ Morphological condition } \\
\cline { 2 - 8 } & $\begin{array}{c}\text { Cross } \\
\text { structures }\end{array}$ & Class 1 & Class 2 & Class 3 & Class 4 & Class 5 & $\begin{array}{c}\text { Overall } \\
\text { Status }\end{array}$ \\
\hline $\begin{array}{l}\text { Rolava River } \\
\text { (WB1, WB3) }\end{array}$ & 25 & 20.7 & 53.5 & 12.6 & 13.2 & 0 & Moderate \\
$\begin{array}{l}\text { Nejdecký } \\
\text { Brook (WB2) }\end{array}$ & 4 & 4.5 & 38.4 & 30.0 & 19.2 & 7.9 & Moderate \\
\hline
\end{tabular}

town (WB-3). Natural sections were identified on the upper course of the Rolava (WB-1) where the river runs through the flat territory of the protected areas Přebuz and Jelení. The upper course of the Nejdecký stream (WB-2) has a natural and near natural condition (class 1 , the middle course is moderately modified (class 2 and 3 ). The habitat of the lower course is strongly to completely changed (class $4-5$ ).

\section{Common characteristics of ecohydrological methods and definition of guiding parameters for ecohydrological river surveys}

Monitoring of general physico-chemical parameters agrees with and follows the WFD requirements in both Germany/Saxony and in Czechia (Appendix V WFD, Enclosure 3 No. 3 SächsWRRLVO). The general parameters (thermal conditions, salinity, oxygenation, nutrient status, acidification) are similar in both countries and support the interpretation of the hydrobiological data (the most sensitive biological component). Stream type specific background values help assess the physico-chemical conditions in comparison to the physicochemical reference conditions (concentration as detected in the absence of disturbing impacts). These background values were published by LAWA (2007) to define the lower limit of reference conditions (limit between high and good status), and are based on maximum/minimum and mean values. A high ecological status requires a high status for the hydromorphological quality elements and the general physico-chemical conditions. Otherwise the ecological status is downgraded to good. With good, moderate, poor or bad status, the general physico-chemical quality elements are not used for the assessment, but for the plausibility test of the biological results. These yield important advice about the general river status and demand for action. A mutual comparison of these values is simple. According to ČSN 757221 (1998), a Cp index of 90\% overrun is calculated and the classification into five quality classes applied in Czechia as a national standard. The monitoring and assessment procedure of the basic physico-chemical quality components in Germany/Saxony is regulated and described by WFD (EC 2000), SächsWRRLVO (2004) and LAWA (2007).

We recommend the following physico-chemical parameters as guiding parameters for the ecohydrological river survey (Table 11): temperature, dis- 
Tab. 11 - Guidelines for ecohydrological river surveys

\begin{tabular}{|c|c|}
\hline Monitoring & Elements and parameters \\
\hline $\begin{array}{l}\text { Hydromorphological } \\
\text { monitoring }\end{array}$ & $\begin{array}{l}\text { Hydrological regime: discharge, quantity and dynamics (mean } \\
\text { annual discharge, minimum and maximum discharge, seasonal- } \\
\text { ity of flow variations), connectivity to ground water body } \\
\text { River continuity: migration barriers, crossings } \\
\text { Morphological conditions: depth variation, width variation; type } \\
\text { of profile, depth of profile; substrate type, bed-fixing, special bot- } \\
\text { tom structures; accumulation forms / bars, erosion; curvature / } \\
\text { sinuosity / braiding, special structures of the river course; flow } \\
\text { character / current diversity; bank vegetation, bank impair- } \\
\text { ments, special bank structures; land-use in floodplain, anthropo- } \\
\text { genic impairments / flood protection measures }\end{array}$ \\
\hline $\begin{array}{l}\text { Hydrobiological } \\
\text { monitoring }\end{array}$ & $\begin{array}{l}\text { Benthic macroinvertebrates: taxonomic composition, number } \\
\text { of taxa, abundance, share of tolerant taxa; degree of diversity; } \\
\text { stream type and stressor specific assessment }\end{array}$ \\
\hline $\begin{array}{l}\text { Hydrochemical } \\
\text { monitoring }\end{array}$ & $\begin{array}{l}\text { General physico-chemical parameters: temperature, dissolved } \\
\text { oxygen, chloride, } \mathrm{P}_{\text {tot }}, \text { o- } \mathrm{PO}_{4}-\mathrm{P}, \mathrm{NH}_{4}-\mathrm{N}, \mathrm{pH} \text {-value, TOC, } \mathrm{BOD}_{5} \text { (in } \\
\text { accordance to LAWA } 2007 \text { ), and } \mathrm{N}-\mathrm{NO}_{3}, \mathrm{COD} \text {, Acidity pH } 4,3 \text {, } \\
\text { Alkalinity pH } 8,2 \text {, conductivity (additional) }\end{array}$ \\
\hline
\end{tabular}

solved oxygen, chloride, $\mathrm{P}_{\text {tot }}, \mathrm{o}-\mathrm{PO}_{4}-\mathrm{P}, \mathrm{NH}_{4}-\mathrm{N}$, $\mathrm{pH}$-value, TOC, $\mathrm{BOD}_{5}$ (in accordance to LAWA 2007), and $\mathrm{N}-\mathrm{NO}_{3}, \mathrm{COD}$, acidity ( $\mathrm{pH} 4.3$ ), alkalinity ( $\mathrm{pH} \mathrm{8.2),}$ and conductivity (additionally).

The hydrobiological monitoring focuses on the biological quality element benthic macroinvertebrates, since these are key-elements of aquatic biota and have been a frequently used organism group for water quality monitoring (De Pauw, Hawkes 1993; Hellawell 1986; Rosenberg, Resh 1993). They are used in both Germany and in Czechia for biological-ecological water quality assessment (saprobity) since the mid 1970s. Thus, long-term data are available as compared to other biological WFD-elements.

To investigate and assess the benthic macroinvertebrates, the German PERLODES method (Meier et al. 2006) and the Czech PERLA method (Kokeš, Němejcová 2006) were applied. Both methods fulfil the requirements of the WFD with regard to a stream type specific assessment in comparison to reference conditions. Results allow statements about the influence of different natural and man-made pressures (acidification, organic pollution, degradation in stream morphology) on macroinvertebrates. Both methods are suitable for shallow running waters and consider different bottom substrates within the sampling site (selection of sampling units by substrate and habitat mapping).

We recommend the following guiding parameters for ecohydrological river survey with benthic macroinvertebrates: taxonomic composition, number of taxa, abundance, fraction of tolerant taxa; degree of diversity (Table 11). The ASTERICS assessment software and the specific methods for the European member states (e.g., Germany: PERLODES method and Czechia: PERLA method) should be used for stream type and stressor specific assessments.

Several methods for river habitat assessment exist. These are mostly used to support biological assessments, e.g., Dodkins et al. (2005) or Schaumburg et al. (2004), and are very well established. However, hydromorphology should be 
taken included as well (Orr et al. 2008), as characterization of geomorphology can be used to explore spatial interactions between the physical habitat and biological data. The condition or health of rivers is influenced by a number of interdependent parameters. As geomorphic processes, operating over an array of scales, determine the physical structure of rivers, geomorphological principles form a logical basis to characterize and assess river habitat (Lehotský 2004).

Instructions and standards by the European Committee for Standardization (CEN 2002; EN 14614:2004) are the basis for hydromorphological surveys, subsequently implemented in the national legislation of EU membership countries. While this basis is similar in all EU member states, relatively high differences in current assessment methods occur. Methods differ from the viewpoint of the zone and reaches delimitation. The number of monitored parameters and zones also differs. All methods have the capacity to identify natural, moderate and even completely changed reaches and provide information on the physical river habitat quality, but vary in respect to their performance - thus differences in invested time, knowledge, and costs occur.

We recommend the following guiding parameters for the ecohydrological river survey (Table 11) in addition to the WFD-requirements on the hydromorphological quality components (with hydrological regime, continuity, and morphological conditions).

\section{Conclusions}

The guidelines for ecohydrological river surveys were selected based on the following principles:

- As many metrics as necessary to attain robust results and to enable a profound data interpretation; as few metrics as possible to guarantee simple applicability.

- Stream type-specific deviations are necessary; however, the approaches for individual stream types should be as similar as possible.

- User friendly metrics, easy to understand and communicate, are preferred.

- All WFD assessment criteria should be covered for hydrological and hydromorphological surveys,

- Reduced requirements for hydrobiological monitoring: benthic macroinvertebrates only, but all WFD-assessment criteria (composition and abundance; share of tolerant taxa; degree of diversity), stream type and stressor specific assessment.

- Reduced requirements for hydrochemical monitoring: general physicochemical parameters only, but all WFD-assessment criteria (thermal conditions, salinity, oxygenation, nutrient status, acidification), and additional parameters.

Our study confirmed that the cooperation of neighbouring countries in ecological assessment of the river habitat is necessary, at least within the integrated river basins, to obtain compatible results and to successfully fulfil the EU WFD requirements. 


\section{References:}

ALF, A., BRAUKMANN, U., MARTEN, M., VOBIS, H. (1992): Biologisch-ökologische Gewässeruntersuchung - Arbeitsanleitung. Handbuch Wasser 2, Landesanstalt für Umweltschutz. Karlsruhe.

AQEM Consortium (2005): AQEM European stream assessment program. Version 2.5, herausgegeben im Mai 2005 - Handbuch für die deutsche Version; http://www.aqem.de. Download: 18.07.2005.

BAIN, M., HARIG, A., LOUCKS, D., GOFORTH, R., MILLS, K. (2000): Aquatic ecosystems protection and restoration: advances in methods for assessment and evaluation. Environmental Science \& Policy, 3, pp. 89-98.

BERNATOWICZ, W., WEIß, A., MATSCHULLAT, J. (2008): Linking biological and physicochemical water quality. Environmental Monitoring and Assessment. Published online: 06.12.2008. DOI: 10.1007/s10661-008-0631-9.

BRAUKMANN, U., BISS, R. (2004): Conceptual study - An improved method to assess acidification in German streams by using benthic macroinvertebrates. Limnologica, pp. 433-450.

ČSN 757221 (1998): Jakost vod. Klasifikace jakosti povrchových vod, 12 pp.

DE PAUW, N., HAWKES, H. A. (1993): Biological monitoring of river water quality. In: Walley, W. J., Judd, S. (eds.): River water quality monitoring and control. Aston University Birmingham. pp. 87-112.

DEV (1992): DIN 38410 Teil 2.10.1990. Deutsches Einheitsverfahren zur Wasser-, Abwasser- und Schlammuntersuchung - Biologisch-ökologische Gewässeruntersuchung (Gruppe M) - Teil 2: Bestimmung des Saprobienindex in Fließgewässern (M1). Deutsches Institut für Normung e.V. 1992.

DEV (1993): Deutsche Einheitsverfahren zur Wasser-, Abwasser- und Schlammuntersuchung, Gruppe A bis K, Deutsches Institut für Normung e.V. Beuth Verlag GmbH, Berlin.

DEV (2004): DIN 38410 Teil 1 10.2004. Deutsches Einheitsverfahren zur Wasser-, Abwasser- und Schlammuntersuchung - Biologisch-ökologische Gewässeruntersuchung (Gruppe M) - Teil 1: Bestimmung des Saprobienindex in Fließgewässern (M1). Deutsches Institut für Normung e.V. Oktober 2004.

DODKINS, X. et al. (2005): Developing an optimal river typology for biological elements within the Water Framework Directive. Water Research, 39, No. 15, pp. 3479-3486.

DIEKMANN, M., DUßLING, U., BERG, R. (2005): Handbuch zum fischbasierten Bewertungssystem für Fließgewässer. (FIBS). Fischereiforschungsstelle Baden-Württemberg, Langenargen.

EN 14614:2004 Water quality - Guidance standard for assessing the hydromorphological features of rivers. November 2004.

EC (2000): Directive 2000/60/EC of the European Parliament and of the Council of 23 October 2000 establishing a framework for Community action in the field of water policy. Official Journal of the European Communities L327, pp. 1-77.

GRULICH, X., VYDROVÁ, X. (2006): Metodika odběru a zpracování vzorku makrofyt tekoucích vod. VÜV T.G.M. Praha, 6 pp.

HAASE, P., SUNDERMANN, A., HERING, D., KORTE, D., MEIER, C., BÖHMER, J., ZENKER, A. (2004): Anwendung und Erprobung neu entwickelter Verfahren zur Fließgewässerbewertung (Makrozoobenthos). Abschlussbericht Dezember 2004. Forschungsinstitut Senckenberg (FKZ O 3.04) 80 pp. + Appendix.

HELLAWELL, J. M. (1986): Biological indicators of freshwater pollution and environmental management. Elsevier London.

HETEŠA, J., MARVAN, P. (2006): Metodika odběru a zpracování vzorků fytoplanktonu tekoucích vod. VÚV T.G.M. Praha, 8 pp.

HRYZÁKOVÁ, K. (2008): Srovnávací analýza jakosti povrchových vod v povodích horní Blanice, Liběchovky a Rolavy. Thesis. PřF UK, Praha, 85 pp.

KOKES J., NĚMEJCOVÁ D. (2006): Metodika odběru a zpracování vzorku makrozoobentosu teskoucích vod metodou PERLA. VÚV T.G.M. Praha, 10 pp.

LANGHAMMER, J. (2007): HEM Hydroekologický monitoring. Metodika pro monitoring hydromorfologických ukazatelů ekologické kvality vodních toků. PřF UK, Praha, 47 pp. 
LANGHAMMER, J. (2008): HEM Hydroekologický monitoring. Metodika pro monitoring hydromorfologických ukazatelů ekologické kvality vodních toků. Hodnocení ukazatelů. PřF UK, Praha, 23 pp.

LAWA (1998): Beurteilung der Wasserbeschaffenheit von Fließgewässern in der Bundesrepublik Deutschland - Chemische Gewässergüteklassifikation. 1. Edition, Kulturbuchverlag Berlin. Laenderarbeitsgemeinschaft Wasser, 69 pp.

LAWA (2000): Gewässerstrukturgütekartierung in der Bundesrepublik Deutschland - Verfahren für kleine und mittelgroße Fließgewässer. Empfehlung. Januar 2000. Länderarbeitsgemeinschaft Wasser.

LAWA (2002): Gewässerstrukturgütekartierung in der Bundesrepublik Deutschland - Übersichtsverfahren. Empfehlungen Oberirdische Gewässer. Entwurf April 2002. Länderarbeitsgemeinschaft Wasser.

LAWA (2007): Rahmenkonzeption Monitoring (RaKon Monitoring), Teil B Bewertungsgrundlagen und Methodenbeschreibungen, Arbeitspapier II „Hintergrund- und Orientierungswerte für physikalisch-chemische Komponenten“. Länderarbeitsgemeinschaft Wasser. Ausschuss „Oberirdische Gewässer und Küstengewässer“, Status: 07.03.2007.

LEDVINKA, O. (2008): Trendy srážko-odtokového režimu v povodí Rolavy. Thesis. PřF UK, Praha, $139 \mathrm{pp}$.

LEHOTSKÝ, M. (2004): Hodnotenia morfológie vodných tokov. Geomorphologia Slovaca, IV, No. 1 , pp. $36-47$.

LELUT, J. (2007): Vodohospodářské revitalizace na podkladě ekomorfologického monitoringu vodních toků; aplikace v modelovém povodí Rolavy. Thesis. PřF UK, Praha, 140 pp.

LELUT, J., MATOUŠKOVÁ, M. (2008): Ekomorfologický monitoring vodních toků v povodí Rolavy. In: Ekohydrologický monitoring vodních toků v kontextu Evropské rámcové směrnice o vodní politice. PřF UK, Praha.

LfUG (2002a): Hydrologisches Handbuch. Teil 1. Pegelverzeichnis. Stand: Januar 2002. Sächsisches Landesamt für Umwelt und Geologie, 46 pp.

LfUG (2002b): Hydrologisches Handbuch. Teil 3. Gewässerkundliche Hauptwerte. Stand: Januar 2002. Sächsisches Landesamt für Umwelt und Geologie, 65 pp.

LfUG (2007): Aufstellung der Überwachungsprogramme in Sachsen - Ausweisung von Messstellen. Sächsisches Landesamt für Umwelt und Geologie, Juli 2007, 19 pp. + Appendix.

LIŠKA, M. (2007): Metodika pro sledování kontaminace ř́ćcních ekosystémů specifickými anorganickými a organickými látkami pomocí bioindikátorových organismů. $15 \mathrm{pp}$.

LUA NRW (Landesumweltamt Nordrhein-Westfalen; 2001): Gewässerstrukturgüte in Nordrhein-Westfahlen - Anleitung für die Kartierung mittelgroßer und großer Fließgewässer, Merkblätter 26, No. 1. Auflage, Düsseldorf.

MATOUŠKOVÁ, M. (2003): Ekohydrologický monitoring vodních toků jako podklad pro revitalizaci vodních toků. Ph.D. Thesis. Charles University in Prague, Faculty of Science, Prague, $218 \mathrm{pp}$.

MATOUŠKOVÂ, M. (2004): Ecohydrological monitoring of the river habitat quality. Geografie, 109, No. 2, pp. 105-116.

MATOUŚKOVÁ, M. (2007): Závěrečná zpráva projektu GAČR 205/05/P102. PřF UK v Praze a GAČR, Praha.

MATSCHULLAT, J., BARTH, A., BERNHOFER, C., BONGAERTS, J., DOSTAL, T., DUNGER, V., HEILMEIER, H., SCHMIDT, J., SCHRÖDER, D. (2005): EMTAL - Einzugsgebiets-Management von Talsperren in Mittelgebirgen - Interdisziplinäres Verbundprojekt im Einzugsgebiet der Weißeritz. In: Möltgen, J., Petry, D. (eds.): Interdisziplinäre Methoden des Flussgebietsmanagements. Workshopbeiträge 15./16.03.2005. Schriftenreihe des Instituts für Geoinformatik, Westfälische Wilhelms-Universität Münster. IfGI prints 21 , pp. $51-62$.

MEIER, C., BOHMER, J., BISS, R., FELD, C., HAASE, P., LORENZ, A., RAWER-JOST, C., ROLAUFFS, P., SCHINDEHÜTTE, K., SCHÖLL, F., SUNDERMANN, A., ZENKER, A., HERING, D. (2006): Weiterentwicklung und Anpassung des nationalen Bewertungssystems für Makrozoobenthos an neue internationale Vorgaben. Abschlussbericht März 2006, 198 pp. + Appendix.

MISCHKE, U., BEHRENDT, H. (2007): Bewertungsverfahren von Fließgewässern mittels Phytoplankton zur Umsetzung der WRRL in Deutschland. Leibniz-Institut für Gewässerökologie und Binnenfischerei (IGB) Berlin. 
ORR, H. G. et al (2008): A predictive typology for characterising hydromorphology. Geomorphology, 100, č. 1-2, 1 August 2008, pp. 32-40.

POTTGIESSER, T., SOMMERHÄUSER, M. (2004): Fließgewässertypologie Deutschlands: Die Gewässertypen und ihre Steckbriefe als Beitrag zur Umsetzung der EU-Wasserrahmenrichtlinie. In: Steinberg, C., Calmano, W., Wilken, R. D., Klapper, H. (eds.): Handbuch der Limnologie. 19. Erg. Lfg. 7/04. VIII-2.1, pp. 1-16 + Appendix.

ROLAUFFS, P., STUBAUER, I., ZAHRÁDKOVÁ, S., BRABEC, K., MOOG, O. (2004): Integration of the saprobic system to the European Water Framework Directive. Hydrobiologia 516, pp. 285-298.

ROSENBERG, D. M., RESH, V. H. (1993): Introduction to freshwater biomonitoring and benthic macroinvertebrates. In: Rosenberg, D. M., Resh, V. H. (eds.): Freshwater Biomonitoring and Benthic Macroinvertebrates. Chapman and Hall, New York.

SächsWRRLVO (2004): Verordnung des Sächsischen Staatsministeriums für Umwelt und Landwirtschaft zur weiteren Umsetzung von Richtlinien der Europäischen Gemeinschaft im Bereich der Wasserpolitik. Sächsische Wasserrahmenrichtlinienverordnung SächsWRRLVO vom 07.12.2004. Sächsisches Gesetz- und Verordnungsblatt Nr. 14 vom 30.12.2004, pp. 610-623.

SCHAUMBURG,J. et al. (2004): Ecological classification of macrophytes and phytobenthos for rivers in Germany according to the water framework directive. Limnologica - Ecology and Management of Inland Waters, 34, č. 4, pp. 283-301.

SCHAUMBURG, J., SCHRANZ, C., STELZER, D., HOFMANN, G., GUTOWSKI, A., FOERSTER, J. (2006): Verfahrensanleitung für die ökologische Bewertung von Fließgewässern zur Umsetzung der EU-Wasserrahmenrichtlinie: Makrophyten und Phytobenthos. Bayerisches Landesamt für Wasserwirtschaft (ed.). Januar 2006.

WEIß, A., MATOUSKOVA, M., MATSCHULLAT J. (2008): Hydromorphological assessment within the EU-Water Framework Directive - trans-boundary cooperation and application to different water basins. Hydrobiologia, 603, pp. 53-72.

WEIß, A., MEIER, H., MATSCHULLAT, J. (2003): Reservoir Catchment Management in Mountainous Regions (EMTAL). In: Röhling, H.-G., Steinbach, V. (eds.): MAEGS 13, Geosciences and the European Water Framework Directory, 10.-13.09.2003 in Hannover, Schriftenreihe Deutsche Geologische Gesellschaft, 28, pp. 141-148.

WEIß, A. (2004): Ist-Zustandsanalyse im Hinblick auf den ökologischen Gewässerzustand am Beispiel der hydromorphologischen Qualitätskomponente. In: Möltgen, J., Petry, D. (eds.): Interdisziplinäre Methoden des Flussgebietsmanagements. Workshopbeiträge 15./16.03.2004. Schriftenreihe des Instituts für Geoinformatik, Westfälische WilhelmsUniversität Münster. IfGI prints 21, pp. 151-160.

WEIß, A. (2005): Integration der Ergebnisse der hydromorphologischen Bestandsaufnahme in ein Gewässermanagement für die Weißeritz - Defizite und deren Konsequenzen. In: Matschullat, J. (ed): Workshop Interdisziplinäres BMBF Verbundprojekt EMTAL - Einzugsgebietsmanagement von Talsperren in Mittelgebirgen. TU Bergakademie Freiberg, Workshopbeiträge 06./07.10.2005, pp. 157-168.

WEIß, A. (2007): Integrierte Bewertung des ökologischen Zustands von Fließgewässern in Mittelgebirgsregionen - Erfahrungen aus der praktischen Umsetzung der EU-Wasserrahmenrichtlinie in Flusseinzugsgebieten des Erzgebirges. PhD-Thesis. TU Bergakademie Freiberg. 227 pp. + Appendix.

Shrnutí

\section{EKOLOGICKÝ PRŮZKUM DIVERZITY ŘÍČNÍHO HABITATU: PŘESHRANIČNÍ SPOLUPRÁCE V KRUŠNÝCH HORÁCH}

Příspěvek prezentuje výsledky př́hraničního ekologického průzkumu v povodích řek Rolavy a Weisseritz v Krušných horách. Cílem je vývoj komplexní metody pro hodnocení ekohydrologického stavu vodních toků se zohledněním evropské Rámcové směrnice o vodní politice (WFD, 2000/60/EC). Nejprve byla zvolena skupina tzv. určujících parametrů pro hydromorfologický průzkum s využitím německé metody „LAWA Gewaesserstrukturguetekartierung“ založené na terénním průzkumu a dále českých metod EcoRivHab a HEM. 
Následně byly výsledky porovnány s požadavky evropské normy EN 14614. Hydrochemický monitoring byl využit jako podpora pro interpretaci hydrobiologických dat. Hodnocení bylo provedeno porovnáním se specifickými pozad’ovými a orientačními hodnotami viz tabulka 1. Hydrobiologický monitoring byl založen na hodnocení makrozoobentosu. Pět ekohydrologických stupňů bylo definováno 1 (vysoký) až 5 (špatný) charakterizující ekologický stav vodního toku v kontextu s Rámcovou směrnicí o vodní politice.

Pro hodnocení ekologického stavu vodních toků doporučujeme následující fyzikálně chemické parametry: teplotu, rozp. $\mathrm{O}_{2}$, chloridy, $\mathrm{P}_{\text {celk }}, \mathrm{NH}_{4}-\mathrm{N}, \mathrm{pH}, \mathrm{C}_{\text {celkorg. }}, \mathrm{BSK}_{5}, \mathrm{~N}_{-} \mathrm{NO}_{3}, \mathrm{CHSK}_{\text {, }}$ aciditu (KNK 4.3), alkalitu (ZNK 8.2) a konduktivitu. Z hydrobiologického pohledu pak hodnocení makrozoobentosu na základě skladby a počtu čeledí, jejich četnosti, podílu tolerantních čeledí a stupně diverzity. Z pohledu hydromorfologických parametrů pak hodnocení hydrologického režimu (variabilita $\mathrm{Q}_{\mathrm{d}}, \mathrm{Q}_{\mathrm{m}}$ ), propojení s podzemní vodou viz EN 14614 (2004), dále hodnocení přítomnosti migračních bariér a př́ičných překážek a v poslední řadě morfologických poměrù (variabilita hloubek a šířek, typ a hloubka profilu, typ substrátu, charakter úpravy dna, specifické dnové struktury, akumulační tvary, speciální struktury vinutí toku, charakter proudění, vegetace břehů, specifické břehové struktury, využití údolní nivy, antropogenní opevnění a protipovodňová opatření.

Ekohydrologický průzkum vodních tokủ by se měl řídit následujícími principy:

- jednoduchostí, jednoznačností a srozumitelností při aplikaci

- specifičností na základě jednotlivých typů vodních toků

- zohlednit veškerá kritéria definovaná WFD pro hydromorfologicky průzkum

- přiměřené požadavky na hydrobiologický průzkum: hodnocení makrozoobentosu na základě požadavků WFD

- reálné nároky na hydrochemický průzkum, tj. hodnocení pouze základních fyzikálně-chemických parametrů

Naše studie potvrdila, že spolupráce sousedních zemí při ekologickém hodnocení kvality říčních habitat je nezbytná, přinejmenším na úrovni jednotných povodí, a to z důvodu získání kvalitních a srovnatelných dat pro naplnění požadavků WFD EU.

Obr. 1 - Povodí řek Weisseritz (a) a Rolava (b) v Krušných horách.

Obr. 2 -Zastoupení čeledí makrozoobentosu ve vodních útvarech v povodí řeky Weisseritz Zdroj dat: LfULG, v korespondenci s A. Biemelt, 6. 2. 2003, rok: 2001.

Obr. 3 - Průměrné měsíční průtoky ve vybraných limnigrafických stanicích v povodí Weisseritz za období 1. 11. 2000 - 31. 10. 2001. Zdroj dat: StUFA Radebeul, v korespondenci s Dr. A. Barth, Beak Consultants GmbH, 2. 8. 2004.

Obr. 4 -Zastoupení čeledí makrozoobentosu ve vodních útvarech v povodí řeky Rolavy. Zdroj dat: Hryzáková 2008.

Obr. 5 - Průměrné roční průtoky v limnigrafické stanici Chaloupky v povodí řeky Rolavy za období 1967-2007. Zdroj dat: CHMI Prague.

M. Matoušková is affiliated with Charles University in Prague, Faculty of Science, Department of Social Geography and Regional Development, Albertov 6, 12843 Prague 2, Czechia; e-mail: matouskova@natur.cuni.cz.A. Weiß is affiliated with Umweltbuero Dr. Annett Wei $\beta$, Heimgarten 120, D-09127 Chemnitz, Germany; e-mail: umweltbuero-weiss@t-online.de. J. Matschullat is affiliated with Interdisciplinary Environmental Research Centre, Technical University Bergakademie Freiberg, Brennhausgasse 14, D-09599 Freiberg, Germany, e-mail:joerg.matschullat@ioez.tu-freiberg.de.

Initial submission 7 December 2009; final acceptance 25 May 2010.

\section{Citační vzor:}

MATOUŠKOVÁ, M., WEIß, A., MATSCHULLAT, J. (2010): Ecological survey of river habitat diversity: trans-boundary cooperation in the Ore Mountains (Krušné hory, Erzgebirge). Geografie, 115, č. 3, s. 284-307. 